\title{
LRRTM2 Gene
}

National Cancer Institute

\section{Source}

National Cancer Institute. LRRTM2 Gene. NCI Thesaurus. Code C88988.

This gene may play a role in the development of the nervous system. 